\title{
Effects of sulfide minerals on aromatic maturity parameters: Laboratory investigation using micro-scale sealed vessel pyrolysis
}

\author{
Alex I. Holman ${ }^{a, *}$, Paul F. Greenwood ${ }^{\mathrm{a}, \mathrm{b}, \mathrm{c}}$, Jochen J. Brocks ${ }^{\mathrm{d}}$, Kliti Grice ${ }^{\mathrm{a}, *}$ \\ ${ }^{a}$ Western Australia Organic and Isotope Geochemistry Centre, Department of Chemistry, The Institute for Geoscience Research, Curtin University, GPO Box U1987, Perth, \\ WA 6845, Australia \\ ${ }^{\mathrm{b}}$ Centre for Exploration Targeting, University of Western Australia, Crawley, WA 6009, Australia \\ ${ }^{c}$ WA Biogeochemistry Centre, University of Western Australia, Crawley, WA 6009, Australia \\ ${ }^{\mathrm{d}}$ Research School of Earth Sciences, The Australian National University, Canberra, ACT 0200, Australia
}

\section{A R T I C L E I N F O}

\section{Article history:}

Received 19 December 2013

Received in revised form 28 August 2014

Accepted 2 September 2014

Available online 16 September 2014

\section{Keywords:}

Micro-scale sealed vessel pyrolysis

Polycyclic aromatic hydrocarbon

Thermal maturity

Thermal simulation

Sulfide

Mineral

\begin{abstract}
A B S T R A C T
Sedimentary organic matter from the Here's Your Chance (HYC) Pb-Zn-Ag deposit (McArthur Basin Northern Territory, Australia) displays increased thermal maturity compared to nearby non-mineralised sediments. Micro-scale sealed vessel pyrolysis (MSSVpy) of an immature, organic rich sediment from the host Barney Creek Formation (BCF) was used to simulate the thermal maturation of OM from the HYC deposit, and to assess the effect of sulfide minerals on organic maturation processes. MSSVpy at increasing temperatures $\left(300,330\right.$ and $\left.360^{\circ} \mathrm{C}\right)$ resulted in increased methylphenanthrene maturity ratios which were within the range reported for bitumen extracted from HYC sediments. The methylphenanthrene index ratio from MSSVpy of the BCF sample was lower than in HYC, due to a reduced proportion of methylated phenanthrenes. Polycyclic aromatic hydrocarbons with four to six rings were produced in increasing abundance as pyrolysis temperature increased, although they did not approach the levels reported from HYC. Addition of lead sulfide, zinc sulfide and pyrite to the MSSVpy experiments resulted in a reduced response of the methylphenanthrene maturity parameters, possibly due to retardation of methyl-shift and transmethylation reactions.
\end{abstract}

(c) 2014 Elsevier Ltd. All rights reserved.

\section{Introduction}

Organic matter $(\mathrm{OM})$ is thought to play an important role in the formation of many commercially viable ore bodies, hence there is significant interest in using organic geochemical techniques to investigate the formation history of ore deposits (Greenwood et al., 2013). OM can be significantly altered by interaction with ore-forming fluids. For example, major hydrothermal events associated with the formation of sedimentary-exhalative (SEDEX) ore deposits have caused a marked increase in the thermal maturity of associated sedimentary OM (Gizè, 1999; Logan et al., 2001; Williford et al., 2011). Oxidised fluids which formed the Kupferschiefer deposit contributed to increased pristane/phytane ratios (Large and Gizè, 1996) and lower abundances of methylated aromatics (Püttmann et al., 1989). The high abundance of sulfide minerals in such environments may be a major influence on the behaviour of OM during alteration, such that traditional

* Corresponding authors. Tel.: +61 (0) 892669387 (A.I. Holman). Tel.: +61 (0) 8 9266 2474; fax: +61 (0) 892662300 (K. Grice).

E-mail addresses: A.Holman@curtin.edu.au (A.I. Holman), K.Grice@curtin.edu.au (K. Grice). assumptions and interpretations largely based on petroleum organic geochemistry may not apply (Gizè, 1999). Although sulfide minerals have been found to catalyse abiotic organic reactions important to the early origins of life (Cody et al., 2004; Cleaves et al., 2012) their effect on the thermal maturation of OM has been largely unexplored.

A wide range of molecular parameters have been developed to assess the thermal maturity of source rocks and petroleum hydrocarbons, summarised by Peters et al. (2005). Parameters based on polycyclic aromatic hydrocarbons (PAHs) such as naphthalene and phenanthrene are widely used due to the ubiquity of these compounds in sediments and their high thermal stability compared to aliphatic biomarkers (Price, 1993). Methylated PAHs readily undergo isomerisation reactions during maturation, with the $\beta$-substituted isomers being more thermodynamically stable than the $\alpha$-isomers (Nabbefeld et al., 2010; Szczerba and Rospondek, 2010; Dick et al., 2013). A number of parameters have been developed based on the relative abundance of methylphenanthrene (MP) isomers, including the methylphenanthrene ratio MPR = 2-MP/1-M (Radke et al., 1982b) and the methylphenanthrene indices MPI-1 = 1.5 (2-MP + 3-MP)/(P + 9-MP + 1-MP) (Radke et al., 1982a $)$ and $\mathrm{MPI}-3=(2-\mathrm{MP}+3-\mathrm{MP}) /(9-\mathrm{MP}+1-\mathrm{MP})$ 
(Garrigues et al., 1988). Catalysis by clay mineral surfaces has been shown in different circumstances to promote methylation or demethylation of PAHs in shales and crude oils (Alexander et al., 1995; van Aarssen et al., 1999) and thus can influence the values of aromatic maturity parameters (Nabbefeld et al., 2010). Larger PAHs with four or more aromatic rings are not generally used in maturity parameters, although they may be produced by burial metamorphism (Brocks et al., 2003) and have been detected in high abundances in submarine hydrothermal petroleum (Kawka and Simoneit, 1990; Simoneit, 1994; Simoneit et al., 2004). PAHs have been detected in a range of ore deposits including sediment-hosted lead-zinc (Chen et al., 2003; Williford et al., 2011), mercury (Blumer, 1975; Wise et al., 1986), copper-silver (Püttmann et al., 1989; Rospondek et al., 2007, 2009) and stratabound copper sulfide (Rieger et al., 2008).

Micro-scale sealed vessel pyrolysis (MSSVpy) is a closed system pyrolysis technique in which relatively small (mg) amounts of organic material are heated in a sealed glass tube. MSSVpy has been widely applied to simulate the catagenetic reactions of hydrocarbons and study the kinetics of petroleum generation (e.g. Horsfield et al., 1989; Schenk and Horsfield, 1993; Ladjavardi et al., 2013), as well as to characterise naturally occurring OM (Greenwood et al., 2006; Berwick et al., 2010; Lockhart et al., 2013) and investigate the formation of specific organic products during diagenesis (Sinninghe Damsté et al., 1998). Another common technique for the artificial maturation of OM is hydrous pyrolysis, in which crushed or powdered rock is heated with water in sealed vessels (Lewan et al., 1979). Compared to MSSVpy, hydrous pyrolysis more holistically replicates the conditions of natural organic maturation due to the presence of water and the control of pressure, fluid composition and redox state (e.g. Landais et al., 1994; Lewan, 1997; Seewald, 2001). However the high pressures generated during hydrous pyrolysis require specialised laboratory equipment, while MSSVpy is easier to employ and generates similar products to natural organic maturation (Horsfield et al., 1989). Here we employ MSSVpy to simulate the thermal maturation of OM from the Here's Your Chance (HYC) $\mathrm{Pb}-\mathrm{Zn}-\mathrm{Ag}$ deposit and to assess the effect of high abundances of sulfide minerals on aromatic maturity parameters.

\section{Materials and methods}

\subsection{Sample site and description}

The Barney Creek Formation (BCF) is a $1640 \pm 3$ Ma (Page and Sweet, 1998) marine shale deposited in the McArthur Basin (Northern Territory, Australia) under reduced, deep water conditions (Bull, 1998). Detailed descriptions are presented by Brocks and Schaeffer (2008) and Greenwood et al. (2013). The BCF is host to the Here's Your Chance (HYC) Pb-Zn-Ag deposit, the largest of the Proterozoic deposits of the North Australian craton which is the world's richest $\mathrm{Pb}-\mathrm{Zn}$ mineral province (Huston et al., 2006). The base metals in HYC are widely believed to have been deposited by a hydrothermal brine with a temperature of $100-200{ }^{\circ} \mathrm{C}$ (Huston et al., 2006; Williford et al., 2011), in a tectonically controlled sub-basin (McGoldrick et al., 2010). A number of studies have investigated the organic geochemistry of HYC (Logan et al., 2001; Chen et al., 2003; Williford et al., 2011) and have found evidence of significant hydrothermal alteration of OM in mineralised sections. Mineralised sections of the deposit contain abundant fine-grained pyrite, sphalerite and galena (e.g. Large et al., 1998; Ireland et al., 2004).

The sample used in this study (referred to as the BCF sample) was taken from the Glyde Sub-basin, from drill core GR-7 at depth $94.69-94.81 \mathrm{~m}$. The Glyde Sub-basin is located $80 \mathrm{~km}$ south of HYC and is stratigraphically equivalent and morphologically similar to the deposit (Davidson and Dashlooty, 1993; McGoldrick et al., 2010). Sediments from the Glyde region often have low thermal maturity for samples of Paleoproterozoic age, with equivalent vitrinite reflectance of 0.6-0.8\% calculated from MPI-1 (Crick, 1992), and contain abundant biomarkers of phototrophic sulfur bacteria including intact carotenoid pigments (Brocks et al., 2005; Brocks and Schaeffer, 2008). Organic matter preserved within the kerogen-mineral matrix of mineralised HYC samples has shown evidence for the presence of these bacteria during ore formation (Holman et al., 2014). The BCF sample was deposited in a similar environment to HYC and displays relatively low thermal maturity. While the sample is not an exact match of the HYC sediments prior to mineralisation, it is a suitable analogue to evaluate the effect of sulfide minerals on the organic maturation processes that occurred during the formation of the deposit.

\subsection{Sample preparation}

The BCF sample had been stored long term in a Whirl-Pak plastic sample bag. Such plastic bags are potential sources of hydrocarbon contamination including branched alkanes with quaternary carbons (BAQCs; e.g. Grosjean and Logan, 2007; Greenwood et al., 2009). Before the sample was powdered, rock pieces were ultrasonically extracted (30 min) with a small amount of Milli-Q purified water to ablate the surfaces of the sample. The water and fine suspended particles were twice shaken with DCM in a separating funnel. The organic layer was reduced with a rotary evaporator and passed through a Pasteur pipette packed with $\mathrm{MgSO}_{4}$ (Fisher Scientific, pre-rinsed with DCM). Three small pieces $(1 \times 1 \mathrm{~cm})$ were cut from the sample bag with scissors (rinsed with DCM) and ultrasonically extracted for $15 \mathrm{~min}$ in DCM. Both extracts were analysed by GC-MS (instrumental conditions detailed in Holman et al., 2012). Analysis of the $m / z$ 99-85 extracted ion chromatogram from the sample bag extract revealed a series of 3,3-diethylalkanes with 21-35 carbon atoms, which are known contaminants from Whirl-Pak sample bags (Grosjean and Logan, 2007). These compounds were not detected in the surface washings from the BCF sample.

The sample was ground to a fine powder in a Rock Labs ring mill with a zirconia head. The mill was cleaned before use by repeated grinding of acid washed, annealed sand. The final batch of ground sand was extracted with DCM and GC-MS analysis showed no significant contamination.

\subsection{Pure metal sulfides}

Zinc sulfide (Purum, Riedel-de Haën, Sigma Aldrich) was received as a fine white powder. Lead sulfide (99.9\%, Aldrich) was in the form of aggregates that were crushed to a fine powder with a mortar and pestle. Pyrite (Alfa Aesar) was received as grains approximately $1.5-5 \mathrm{~mm}$ in length, which were powdered in a Rock-Labs ring mill with a zirconia head. Sulfides were cleaned by ultrasonic extraction $(\times 3)$ with DCM. Analysis of the final extract by GC-MS showed no significant contaminants.

To examine the size distribution of the sulfides, particles were suspended in deionized water, transferred to microscope slides and imaged on an optical microscope under transmitted light. The sulfides consisted of fine particles, often sub-micrometre in size, commonly aggregated into clusters ranging from ten to several hundred micrometres. Previous investigations of sulfide mineral textures in the HYC deposit have found that sulfide minerals occur in grains of $1-10 \mu \mathrm{m}$, aggregated into clusters of 20 $200 \mu \mathrm{m}$ (Eldridge et al., 1993; Ireland et al., 2004). The pure sulfides used in this study are therefore an adequate approximation of the sulfide minerals occurring in HYC. 
Table 1

Precise weights of BCF sample and metal sulfide for the mixtures sub-sampled for MSSVpy experiments.

\begin{tabular}{llcr}
\hline Sample name & BCF sample $(\mathrm{mg})$ & Metal sulfide $(\mathrm{mg})$ & Sulfide $(\mathrm{wt} \%)$ \\
\hline $5 \% \mathrm{PbS}$ & 961.45 & 54.04 & 5.32 \\
$20 \% \mathrm{PbS}$ & 865.98 & 216.57 & 20.01 \\
$5 \% \mathrm{ZnS}$ & 968.86 & 50.96 & 5.00 \\
$20 \% \mathrm{ZnS}$ & 783.12 & 196.76 & 20.08 \\
$5 \% \mathrm{Py}$ & 954.88 & 49.26 & 4.91 \\
$20 \% \mathrm{Py}$ & 796.24 & 196.90 & 19.83 \\
\hline
\end{tabular}

Mixtures of BCF sample with approximately 5 wt\% and $20 \mathrm{wt} \%$ metal sulfides were prepared and homogenised with a mortar and pestle. Precise weights for all mixtures are listed in Table 1.

\subsection{Micro-scale sealed vessel pyrolysis and GC-MS analysis}

MSSVpy followed a previously described procedure (Greenwood et al., 2006; Berwick et al., 2010). Extractable organic matter was not removed from the sample prior to pyrolysis. Glass tubes ( $5 \mathrm{~cm} \times 5 \mathrm{~mm}$ i.d.) and glass beads (Alltech 60/80) were cleaned by heating overnight at $300^{\circ} \mathrm{C}$ before use. Typically $6-$ $10 \mathrm{mg}$ of sample was loaded into the centre of the tube and the void space above and below the sample was filled with glass beads. The tubes were flame sealed before heating in an oven for $72 \mathrm{~h}$ at either $300{ }^{\circ} \mathrm{C}, 330^{\circ} \mathrm{C}$ or $360^{\circ} \mathrm{C}$. The tubes were then placed in a series II MSSV injector (held at $300^{\circ} \mathrm{C}$ ) mounted on a GC-MS (Agilent 6890 GC coupled to an Agilent 5973 MSD) and cracked with a plunger. Volatile products were transferred to the GC column (Agilent J\&W DB5-MS, $60 \mathrm{~m} \times 0.25 \mathrm{~mm}$ i.d., $0.25 \mu \mathrm{m}$ film thickness) with He carrier gas at a constant pressure of 9 psi, and a split ratio of 20:1. The oven was held at $40^{\circ} \mathrm{C}$ for 2 min while the column was immersed in liquid nitrogen to cryogenically focus the products. The oven temperature was increased from $40^{\circ} \mathrm{C}$ to $320^{\circ} \mathrm{C}$ at $4{ }^{\circ} \mathrm{C} / \mathrm{min}$ then held at $320^{\circ} \mathrm{C}$ for $35 \mathrm{~min}$. Mass spectra were acquired in full scan mode $(m / z 25-550)$ with an ionisation energy of $70 \mathrm{eV}$. All samples were prepared and analysed in duplicate. Product assignments were based on GC retention time and mass spectral comparison with standards or library data.

\subsection{Correction factors}

Due to the online nature of MSSVpy the pyrolysates cannot be separated into saturate and aromatic fractions prior to GC-MS analysis. The GC chromatograms produced in this study contain products which fully or partially co-elute and accurate integration of the total ion chromatogram (TIC) was often difficult for compounds of low abundance (see Fig. 1 for a representative chromatogram). For this reason aromatic compounds were integrated from extracted ion chromatograms (EIC) of diagnostic ions. The selected ion makes up a different proportion of the total mass spectrum for each compound; hence ratios calculated from EIC cannot be directly compared to those from TIC. Correction factors were thus determined for each aromatic compound of interest by calculating the ratio of peak area from EIC to TIC from previous samples run on the GC-MS instrument. Only compounds free from co-elution were included in the calculations, and a range of peak areas were chosen to ensure linearity of the calibration. Calculated correction factors are listed in Table 2 .

\section{Simulated maturation of Barney Creek sediment by MSSVpy}

\subsection{Overall product distribution}

A representative chromatogram from MSSVpy of the BCF sample $\left(300^{\circ} \mathrm{C}\right)$ is shown in Fig. 1 . The most abundant products are listed in Table 3. Aliphatic products from MSSVpy were predominantly normal and methylated alkanes (marked with closed and open circles, respectively). Low molecular weight alkanes $\left(C_{4}-C_{9}\right)$ displayed a higher proportion of methylation. n-Alkanes $>C_{10}$
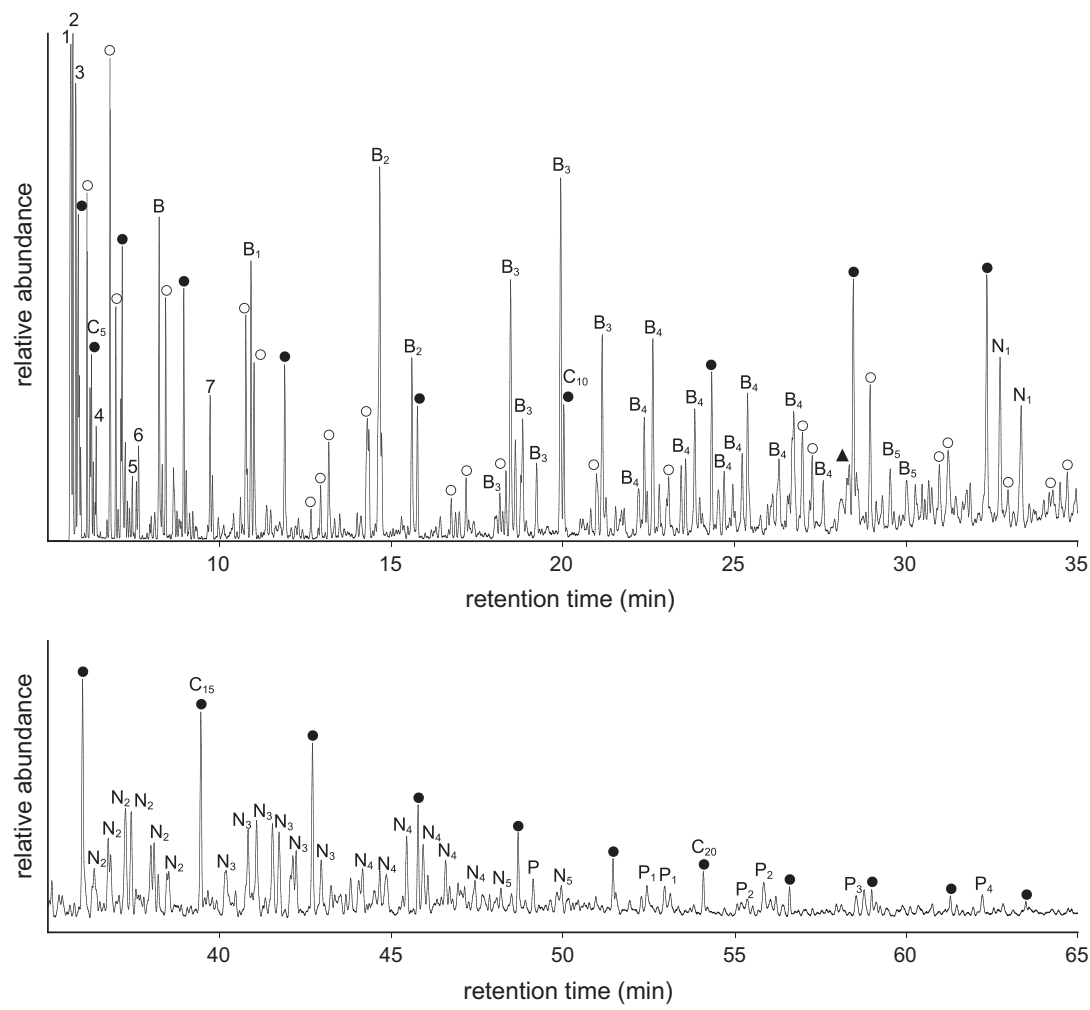

Fig. 1. Total ion chromatogram from MSSVpy of the BCF sample, pyrolysed at $300{ }^{\circ} \mathrm{C}$ for $72 \mathrm{~h}$, with no added metal sulfides. Labelled peaks are listed in Table 3 . 
Table 2

Diagnostic ions and mass spectral correction factors for major PAH products.

\begin{tabular}{lll}
\hline Compound & Diagnostic ion & Correction factor \\
\hline Phenanthrene & 178 & 0.45 \\
Methylphenanthrenes & 192 & 0.34 \\
Pyrene & 202 & 0.37 \\
Chrysene + triphenylene & 228 & 0.37 \\
Benzo[e]pyrene & 252 & 0.30 \\
Benzo[ghi]perylene & 276 & 0.46 \\
\hline
\end{tabular}

displayed a unimodal distribution with a maximum at $\mathrm{C}_{13}$, a long tail extending to $C_{31}$ and a lower proportion of methylated isomers. Low MW alkenes, cycloalkanes and ketones were present in relatively low abundances. The major aromatic products were benzenes and naphthalenes with 1-5 methyl groups. Phenanthrenes and high MW PAHs with 4-7 aromatic rings were present in much lower abundance (see Sections 3.2 and 3.3). Pyrolysis at higher temperatures gave similar results, with the most significant difference being an increase in the abundance of high MW PAHs, consistent with the increase in PAH abundance observed across a thermal gradient at HYC (Chen et al., 2003) (see Fig. 2 and Section 3.3 for discussion).

Solvent extracted bitumens from the BCF contain abundant aryl isoprenoids (Brocks et al., 2005; Brocks and Schaeffer, 2008), which are formed from the breakdown of microbial carotenoids (Summons and Powell, 1987; Grice et al., 1996, 1997; Koopmans et al., 1996). These were not detected in the MSSVpy experiments. Pyrolysis of long chain alkylbenzenes has been shown to produce methylbenzene through cleavage of the alkyl $\mathrm{C}-\mathrm{C}$ bond in the $\beta$ position to the aromatic ring, a mechanism favoured by the high stability of the benzyl radical intermediate (Safarik and Strausz, 1997). Cleavage of the alkyl chain from the aryl isoprenoids present in the BCF bitumen would produce tetramethylbenzenes with a predominant 1,2,3,4 substitution pattern. Abundant 1,2,3,4tetramethylbenzene was noted from flash pyrolysis of sedimentary organics from the Duvernay Fm. (Western Canada Sedimentary Basin) and was attributed to the breakdown of di-aromatic carotenoids (Hartgers et al., 1994; Maslen et al., 2009). In the MSSVpy products from this study the mono-, di- and trimethylbenzenes were more abundant than the tetramethylbenzenes. It is likely they were produced by demethylation and methyl shift reactions (e.g. Szczerba and Rospondek, 2010; Le Métayer et al., 2014) resulting in a larger suite of polymethylated products.

\subsection{Methylated phenanthrene ratios}

The average values for three commonly used methylphenanthrene (MP) maturity parameters (MPI-1, MPR and MPI-3) from the replicate MSSVpy experiments are listed in Table 4, with the range of replicate measurements in parentheses. The reproducibility was in most cases within 5\%. For the pure BCF sample, the maturity parameters increased with pyrolysis temperature, consistent with their behaviour during natural maturation (Radke et al., 1982a). The average MPI- 1 values correspond to equivalent vitrinite reflectance values of 0.89 at $300{ }^{\circ} \mathrm{C}$ to 1.16 at $360^{\circ} \mathrm{C}$, using the calibration of Boreham et al. (1988).

The calculated MP ratios were compared to those from HYC bitumens reported by Williford et al. (2011), which are shown by the shaded areas in Fig. 3A-C. The ratios using only MP isomers (MPR and MPI-3) display similar behaviour in comparison to HYC bitumen. The BCF sample pyrolysed at $300{ }^{\circ} \mathrm{C}$ gave values slightly below the minimum reported from HYC. At $330^{\circ} \mathrm{C}$ the values lie at the middle of the $\mathrm{HYC}$ range, while at $360^{\circ} \mathrm{C}$ values significantly exceed the maximums reported for HYC. Unlike MPR and MPI-3, the MPI-1 ratio includes unmethylated phenanthrene as well as
Table 3

Major products from MSSVpy of the BCF sample at $300{ }^{\circ} \mathrm{C}$ for $72 \mathrm{~h}$, with no added metal sulfides.

\begin{tabular}{llll}
\hline Label & Compound & Label & Compound \\
\hline 1 & $\mathrm{CO}_{2}$ & $\mathrm{~B} 4$ & $\mathrm{C}_{4}$ benzenes \\
2 & Propene & $\mathrm{B} 5$ & $\mathrm{C}_{5}$ benzenes \\
3 & 2-Methylpropane & $\mathrm{N}$ & Naphthalene \\
4 & 3-Methylbut-1-ene & $\mathrm{N} 1$ & Methylnaphthalenes \\
5 & Methylpent-2-ene & $\mathrm{N} 2$ & $\mathrm{C}_{2}$ naphthalenes \\
6 & Methylcyclopentane & $\mathrm{N} 3$ & $\mathrm{C}_{3}$ naphthalenes \\
7 & Methylcyclohexane & $\mathrm{N} 4$ & $\mathrm{C}_{4}$ naphthalenes \\
- & n-Alkanes & $\mathrm{N} 5$ & $\mathrm{C}_{5}$ naphthalenes \\
0 & Methyl alkanes & $\mathrm{P}$ & Phenanthrene \\
$\mathrm{B}$ & Benzene & $\mathrm{P} 1$ & Methylphenanthrenes \\
$\mathrm{B} 1$ & Toluene & $\mathrm{P} 2$ & $\mathrm{C}_{2}$ phenanthrenes \\
$\mathrm{B} 2$ & $\mathrm{C}_{2}$ benzenes & $\mathrm{P} 3$ & $\mathrm{C}_{3}$ phenanthrenes \\
$\mathrm{B} 3$ & $\mathrm{C}_{3}$ benzenes & $\mathrm{P} 4$ & $\mathrm{C}_{4}$ phenanthrenes \\
\hline
\end{tabular}

MP isomers. Whilst MPI-1 values similarly increased with higher pyrolysis temperatures, they differed from the range reported for HYC (Fig. 3A). MSSVpy at $300^{\circ} \mathrm{C}$ and $330^{\circ} \mathrm{C}$ gave MPI- 1 values that were significantly lower than the minimum observed from HYC, and only the value at $360{ }^{\circ} \mathrm{C}$ was within the range of HYC. The MPI-1 values from MSSVpy were effectively lower than MPR and MPI-3 in comparison to the reported values from HYC.

The total abundances of the MP isomers relative to phenanthrene (referred to in this study as MP/P) is from 2.7-3.9 for all MSSVpy experiments, and generally decreased slightly from $300{ }^{\circ} \mathrm{C}$ to $360^{\circ} \mathrm{C}$ pyrolysis temperature. For HYC the MP/P ratio is from 5.0-9.3 (Williford et al., 2011). An increased proportion of phenanthrene in the MSSVpy experiments is responsible for a lowering of MPI-1 values. Pyrolysis can promote the cleavage of alkyl groups from aromatic molecules (Safarik and Strausz, 1997), which may account for the low abundances of MPs observed from MSSPpy experiments. Additionally, oxidation of OM during pyrolysis may result in a lowering of the MPI- 1 and MP/P ratios. Phenanthrene has a higher average oxidation state of carbon than the MP isomers $(-0.71$ compared to -0.8$)$. The values of MPI- 1 and MP/P are therefore sensitive to changes in redox conditions as well as temperature, and oxidation of OM would be expected to decrease the $\mathrm{MP} / \mathrm{P}$ ratio and lower the value of MPI-1 (Szczerba and Rospondek, 2010; Dick et al., 2013). A reduction in MPI-1 corresponding to a shift from reducing to oxidising conditions has been observed in the Kupferschiefer deposit (Püttmann et al., 1989; Sun, 1998). However, the use of glass beads to fill the majority of void space within the tube essentially renders the MSSVpy technique free of oxidation artefacts (Horsfield et al., 2015). Indeed the observed increase of MPI-1 with pyrolysis temperature (Fig. 3A) shows that temperature is the major control on MPI- 1 in these experiments.

Alternatively an additional mechanism that was not present in the MSSVpy experiments may have produced MPs at HYC. One potential explanation is the migration of aromatic hydrocarbons to HYC with the mineralising fluid. Williford et al. (2011) found that PAHs from HYC have similar $\delta^{13} \mathrm{C}$ to kerogen from the underlying Wollogorang Fm. and proposed that PAHs were generated in the Wollogorang Fm. by hydrothermal alteration and deposited in the BCF by the mineralising fluid. It is unclear however if these PAHs would have a greater ratio of MP/P than those produced by MSSVpy in this study. The Wollogorang Fm. has experienced extensive metamorphism from volcanic intrusions (Donnelly and Jackson, 1988), which has likely resulted in the destruction of all indigenous organic matter (Brocks et al., 2008). The composition of indigenous $\mathrm{OM}$ from this formation therefore remains uncertain and the likelihood of this explanation cannot presently be evaluated. 

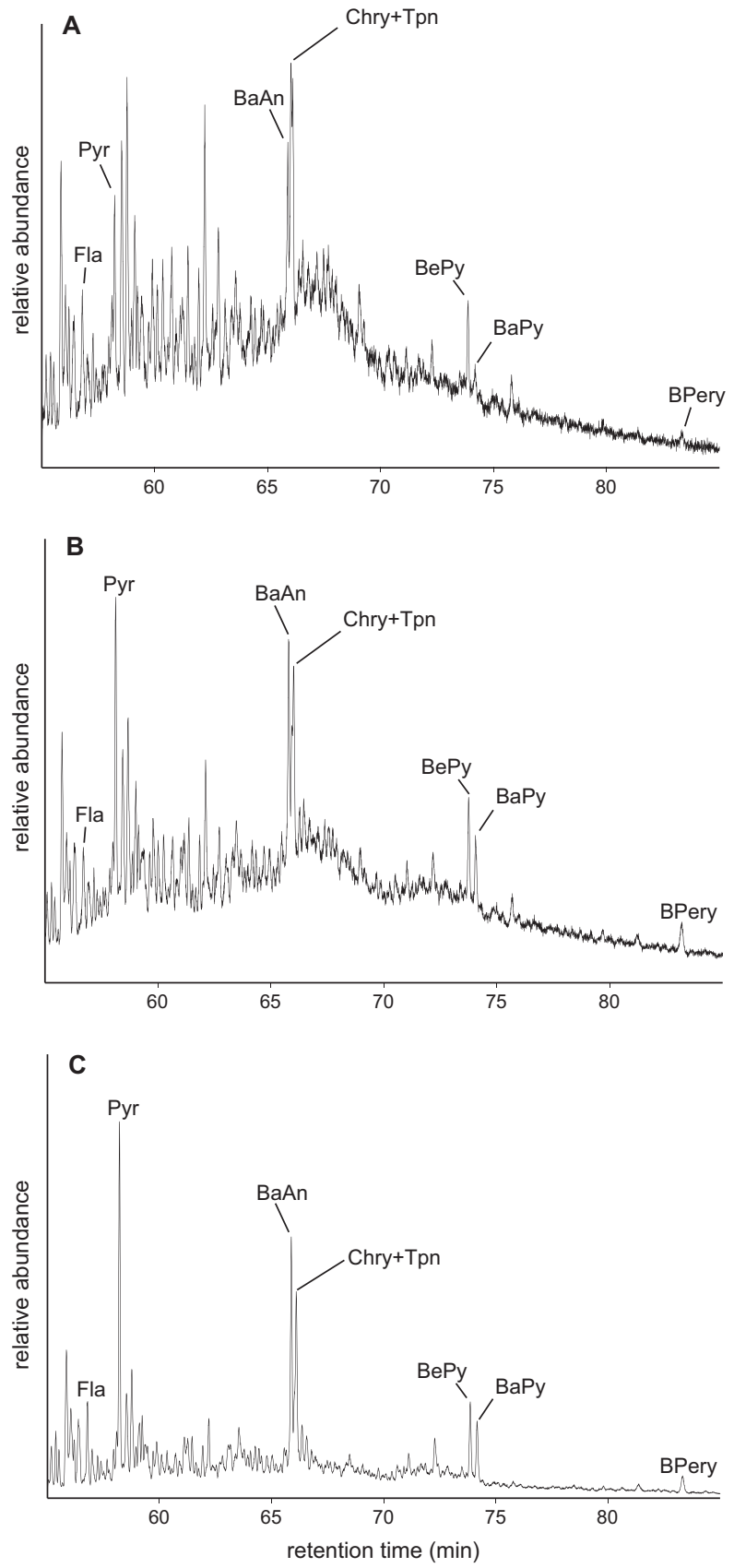

Fig. 2. Summed $m / z 202+228+252+276$ chromatograms from MSSVpy of the BCF sample at each pyrolysis temperature, with no added metal sulfides. Pyrolysis temperature are (A) $300^{\circ} \mathrm{C}$, (B) $330^{\circ} \mathrm{C}$, (C) $360^{\circ} \mathrm{C}$. Fla: fluoranthene, Pyr: pyrene, BaAn: benzo[a]anthracene, Chry: chrysene, Tpn: triphenylene, BePy: benzo[e]pyrene, BaPy: benzo[a]pyrene, BPery: benzo[ghi]perylene.

\subsection{High MW PAHs}

PAHs with 4-6 aromatic rings (hereby collectively referred to as high MW PAHs) were detected at low abundance in all MSSVpy experiments. Summed $m / z 202+228+252+276$ chromatograms for the three pyrolysis temperatures are shown in Fig. 2. At $300{ }^{\circ} \mathrm{C}$ the four-ring PAHs fluoranthene and pyrene have lower abundance than other peaks in the $m / z 202$ chromatogram (mainly dimethyl- and trimethylphenanthrenes), while the five and sixring PAHs are present only in trace amounts. At $330^{\circ} \mathrm{C}$ and $360{ }^{\circ} \mathrm{C}$ the PAHs become far more prominent, implying increased production of high MW PAHs at higher pyrolysis temperature. This
Table 4

PAH ratios measured from MSSVpy analyses. Values are reported as the average of duplicate measurements, with the range of measurement in parentheses.

\begin{tabular}{|c|c|c|c|}
\hline & $300^{\circ} \mathrm{C}$ & $330^{\circ} \mathrm{C}$ & $360^{\circ} \mathrm{C}$ \\
\hline \multicolumn{4}{|l|}{$B C F$} \\
\hline MPI-1 & $0.96(0.02)$ & $1.07(0.05)$ & $1.34(0.01)$ \\
\hline MPR & $1.07(0.06)$ & $1.24(0.04)$ & $1.69(0.06)$ \\
\hline MPI-3 & $1.05(0.03)$ & $1.15(0.07)$ & $1.58(0.01)$ \\
\hline $\mathrm{MP} / \mathrm{P}$ & $3.21(0.01)$ & $3.51(0.04)$ & $3.39(0.02)$ \\
\hline $\mathrm{PAH} / \mathrm{P}$ & $0.45(0.01)$ & $0.77(0.04)$ & $0.91(0.02)$ \\
\hline \multicolumn{4}{|c|}{$B C F+5 \% P b S$} \\
\hline MPI-1 & $1.04(0.01)$ & $0.98(0.08)$ & $1.17(0.03)$ \\
\hline MPR & $1.15(0.03)$ & $1.23(0.03)$ & $1.52(0.04)$ \\
\hline MPI-3 & $1.11(0.04)$ & $1.08(0.06)$ & $1.34(0.01)$ \\
\hline $\mathrm{MP} / \mathrm{P}$ & $3.47(0.13)$ & $3.24(1.07)$ & $3.24(0.16)$ \\
\hline $\mathrm{PAH} / \mathrm{P}$ & $0.37(0.05)$ & $0.57(0.29)$ & $0.51(0.31)$ \\
\hline \multicolumn{4}{|c|}{$B C F+20 \% P b S$} \\
\hline MPI-1 & $1.14(0.06)$ & $1.02(0.04)$ & $1.15(0.01)$ \\
\hline MPR & $1.25(0.05)$ & $1.26(0.03)$ & $1.42(0.04)$ \\
\hline MPI-3 & $1.21(0.03)$ & $1.09(0.08)$ & $1.28(0.01)$ \\
\hline $\mathrm{MP} / \mathrm{P}$ & $3.75(0.31)$ & $3.47(0.18)$ & $3.42(0.05)$ \\
\hline $\mathrm{PAH} / \mathrm{P}$ & $0.24(0.29)$ & $0.43(0.03)$ & $0.69(0.03)$ \\
\hline \multicolumn{4}{|c|}{$B C F+5 \% Z n S$} \\
\hline MPI-1 & $1.06(0.12)$ & $1.06(0.01)$ & $1.16(0.01)$ \\
\hline MPR & $1.21(0.11)$ & $1.24(0.05)$ & $1.49(0.13)$ \\
\hline MPI-3 & $1.20(0.03)$ & $1.13(0.01)$ & $1.38(0.11)$ \\
\hline $\mathrm{MP} / \mathrm{P}$ & $3.22(0.72)$ & 3.55 (0.09) & $3.08(0.42)$ \\
\hline $\mathrm{PAH} / \mathrm{P}$ & $0.29(0.24)$ & $0.70(0.16)$ & $0.53(0.19)$ \\
\hline \multicolumn{4}{|c|}{$B C F+20 \% Z n S$} \\
\hline MPI-1 & $1.03(0.12)$ & $1.03(0.01)$ & $1.15(0.01)$ \\
\hline MPR & $1.12(0.03)$ & $1.20(0.01)$ & $1.43(0.01)$ \\
\hline MPI-3 & $1.16(0.01)$ & $1.17(0.01)$ & $1.36(0.01)$ \\
\hline $\mathrm{MP} / \mathrm{P}$ & $3.19(0.92)$ & $3.09(0.09)$ & $3.07(0.01)$ \\
\hline $\mathrm{PAH} / \mathrm{P}$ & $0.30(0.3)$ & $0.35(0.08)$ & $0.57(0.01)$ \\
\hline \multicolumn{4}{|c|}{$B C F+5 \% P y$} \\
\hline MPI-1 & $1.21(0.08)$ & $1.14(0.02)$ & $1.30(0.01)$ \\
\hline MPR & $1.31(0.03)$ & $1.22(0.01)$ & $1.51(0.01)$ \\
\hline MPI-3 & $1.29(0.02)$ & $1.21(0.04)$ & $1.47(0.01)$ \\
\hline $\mathrm{MP} / \mathrm{P}$ & $3.85(0.85)$ & $3.78(0.13)$ & $3.57(0.01)$ \\
\hline $\mathrm{PAH} / \mathrm{P}$ & $0.34(0.19)$ & $0.78(0.13)$ & $0.57(0.01)$ \\
\hline \multicolumn{4}{|c|}{$B C F+20 \% P y$} \\
\hline MPI-1 & $1.17(0.04)$ & $1.02(0.08)$ & $1.26(0.01)$ \\
\hline MPR & $1.30(0.08)$ & $1.15(0.01)$ & $1.52(0.01)$ \\
\hline MPI-3 & $1.31(0.15)$ & $1.13(0.08)$ & $1.49(0.01)$ \\
\hline $\mathrm{MP} / \mathrm{P}$ & $3.45(1.01)$ & $3.17(0.2)$ & $3.21(0.01)$ \\
\hline $\mathrm{PAH} / \mathrm{P}$ & $0.36(0.36)$ & $0.73(0.2)$ & $0.54(0.01)$ \\
\hline
\end{tabular}

is consistent with observations across a thermal gradient at HYC (Chen et al., 2003; Williford et al., 2011).

The summed abundance of the high MW PAHs fluoranthene, pyrene, benzo[a]anthracene, chrysene, triphenylene, benzo[e] pyrene, benzo[a]pyrene and benzo[ghi]perylene relative to the abundance of phenanthrene is defined here as $\mathrm{PAH} / \mathrm{P}$. This ratio increases with pyrolysis temperature, approximately doubling from $300{ }^{\circ} \mathrm{C}$ to $360{ }^{\circ} \mathrm{C}$ (see Table 4 and Fig. 3D). Phenanthrene was reported to be totally stable during hydrous pyrolysis at $330^{\circ} \mathrm{C}$ for up to 17 days (McCollom et al., 1999) and even persisted after pyrolysis at $400{ }^{\circ} \mathrm{C}$ for 30 days (Price, 1993), therefore destruction of the phenanthrene ring system is not expected to occur at the conditions used in this study. The increased PAH/P ratio is attributed to the increased production of high MW PAHs at higher pyrolysis temperatures.

Bitumen isolated from the HYC deposit contains a high proportion of high MW PAHs, with the samples from Williford et al. (2011) displaying $\mathrm{PAH} / \mathrm{P}$ ratios from 2.2-7.9. In contrast all MSSVpy experiments showed $\mathrm{PAH} / \mathrm{P}$ ratios of $<1.0$ (Fig. 3D) due to the greatly reduced abundances of high MW PAHs. It has been proposed that high MW PAHs in hydrothermal systems are formed by the condensation of low MW organic precursors (Kawka and 

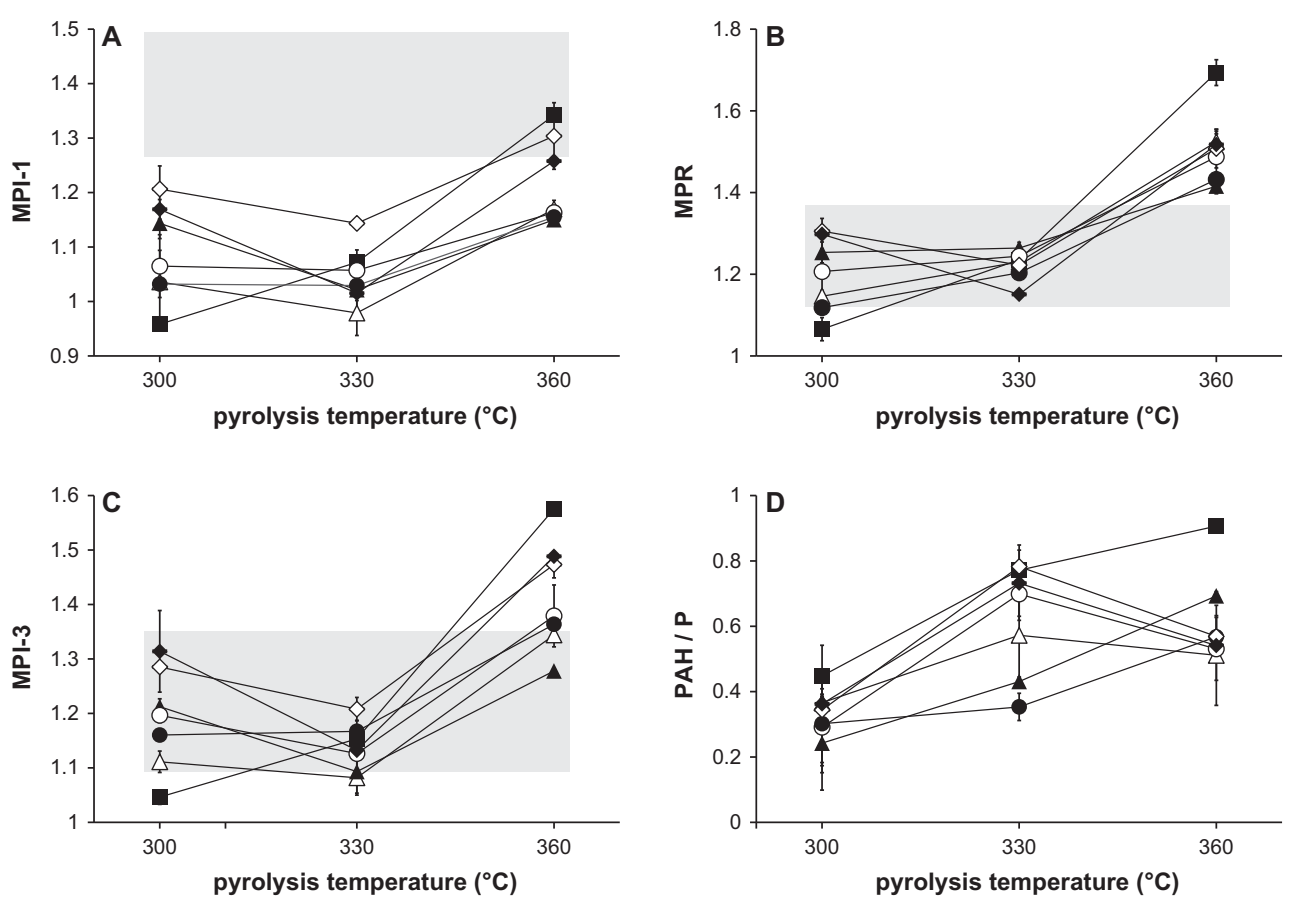

- BCF $\triangle 5 \% \mathrm{PbS} \quad \Delta 20 \% \mathrm{PbS} \quad \mathrm{O} \% \mathrm{ZnS}$

- $20 \% \mathrm{ZnS} \diamond 5 \% \mathrm{Py} \diamond 20 \% \mathrm{Py}$

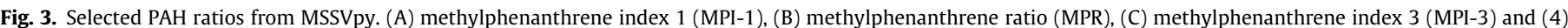

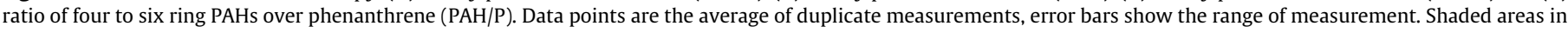
A to $C$ represent the range from the HYC deposit reported by Williford et al. (2011). The range of PAH/P reported by Williford et al. (2011) is 2.2-7.9.

Simoneit, 1990; Fetzer et al., 1996) through the addition of $C_{2}$ or $\mathrm{C}_{4} \mathrm{H}_{2}$ units to existing aromatic structures (Stein, 1978). There would likely be sufficient organic precursors present in the BCF sediment to form significant amounts of high MW PAHs, suggesting that the low abundances of these compounds were due to the thermal conditions used during MSSVpy treatments. Higher temperatures or longer term experiments may be required to generate large abundances of high MW PAHs. Chen et al. (2003) proposed that high MW PAHs were concentrated at HYC by precipitation from hydrothermal fluid, due to the lower aqueous solubility of heavy aromatics compared to two- and three-ringed PAHs (Kawka and Simoneit, 1990). Such a mechanism may contribute to the increased abundances of high MW PAHs at HYC compared to the MSSVpy experiments.

\section{Effects of metal sulfides on simulated thermal maturation}

\subsection{Methylated phenanthrene ratios}

The addition of $\mathrm{PbS}, \mathrm{ZnS}$ and pyrite had a marked effect on all MP ratios (Fig. $3 \mathrm{~A}-\mathrm{C}$ ). At $300^{\circ} \mathrm{C}$ pyrolysis temperature all ratios were higher than the pure $\mathrm{BCF}$ sample. At $330^{\circ} \mathrm{C}$ the ratios were roughly equal with and without added metal sulfides, while at $360{ }^{\circ} \mathrm{C}$ the ratios were notably lower with added metal sulfides. Some samples also displayed a slight decrease in MP ratios from $300{ }^{\circ} \mathrm{C}$ to $330{ }^{\circ} \mathrm{C}$, suggesting an inversion of the maturity parameters in this temperature range. MP maturity ratios from experiments with each sulfide mineral, and with $5 \mathrm{wt} \%$ and $20 \mathrm{wt} \%$ sulfide addition, were all generally within uncertainty.

MP maturity ratios may be influenced by the preferential adsorption of certain isomers onto the sulfide mineral surfaces. In a previous study of the HYC deposit it was found that the $\beta$-MP isomers are more readily extracted with organic solvent than the $\alpha$ isomers (Holman et al., 2012). Preferential retention of $\alpha$-MP isomers by mineral surfaces would result in a decrease in apparent maturity. It is likely however that adsorption effects played only a minor role in the observed behaviour of the MP ratios in this study. Strong organic adsorption is generally observed on clay minerals (Lahav and Chang, 1976; Cleaves et al., 2012), not metal sulfides. Adsorption effects are expected to be proportional to mineral surface area (Cleaves et al., 2012), so it would be expected that experiments with $20 \mathrm{wt} \%$ sulfide minerals added would display stronger effects than those with 5 wt\% sulfides. Fig. 3 shows this is not the case, with little difference being observed between $5 \mathrm{wt} \%$ and $20 \mathrm{wt} \%$ sulfides in most cases. This argues against the strong influence of adsorption effects.

Alternatively the metal sulfides may be acting to catalyse or retard the isomerisation of MPs. Transition metal sulfides are known to act as surface catalysts for a number of sedimentary organic reactions (Wächtershäuser, 1988; Cody et al., 2004). During thermal maturation MPs undergo a range of methyl-shift and transmethylation reactions (Szczerba and Rospondek, 2010) which may be retarded by the presence of metal sulfides. The overall effect on the MP maturity parameters will be determined by the kinetics of each individual isomerisation reaction and will require more detailed studies to fully elucidate.

\subsection{High MW PAHs}

The addition of sulfide minerals caused a decrease in the production of high MW PAHs (Fig. 3D). This is especially apparent at higher pyrolysis temperatures, where the average $\mathrm{PAH} / \mathrm{P}$ ratio decreased from 0.91 for the pure BCF sample to between 0.51 and 0.69 when sulfide minerals were added. Further interpretation of this relationship is limited by the high degree of uncertainty in the analysis of several samples, with the $\mathrm{PAH} / \mathrm{P}$ ratio of some replicates varying by $>50 \%$. Fluoranthene and chrysene/triphenylene are both significantly affected by co-eluting peaks even when 
integrated using the $m / z 202$ and 228 chromatograms, while five and six ring PAHs were of such low abundance, especially at $300{ }^{\circ} \mathrm{C}$ pyrolysis temperature (Fig. $2 \mathrm{~A}$ ), that they were difficult to integrate above the background noise. Nevertheless the ratio of $\mathrm{PAH} / \mathrm{P}$ for all MSSVpy experiments with added sulfide minerals was lower than those for the pure BCF sample. The reason for this reduction is currently unclear. The metal sulfide surfaces may inhibit the addition reactions by which high MW PAHs are assembled from smaller aromatic units. As discussed in Section 3.2, the MPI-1 and $\mathrm{PAH} / \mathrm{P}$ ratios are sensitive to changes in redox conditions. Sulfide minerals are redox active and thus may influence the redox conditions of the MSSVpy experiments, however oxidation during pyrolysis is negligible due to the very low void space within the MSSV tubes (Horsfield et al., 2015).

\section{Conclusions}

MSSVpy has been successfully used to simulate thermal maturation of OM from the BCF. MSSVpy of thermally immature sediment produced a distribution of hydrocarbon products including $n$ alkanes, two and three-ring PAHs and their methylated isomers, typical of thermally mature organic sediments associated with mineralised regions of HYC. Methylphenanthrene maturity parameters measured from MSSVpy of BCF OM fell within the range previously reported from HYC, although the MPI-1 ratio was comparatively lower due to a greater proportion of unmethylated phenanthrene. PAHs with 4-6 aromatic rings were produced in increasing amounts at higher pyrolysis temperatures, but their relative abundance does not approach the levels reported at HYC. The temperature and time conditions used in this study may have been insufficient to form these compounds in high abundances. The increased maturity parameters and the production of high MW PAHs were similar to those attributed to the hydrothermal alteration of sedimentary OM. The addition of metal sulfides consistently affected the values of MP maturity ratios, with an increase at $300^{\circ} \mathrm{C}$ pyrolysis temperature and a decrease at $360^{\circ} \mathrm{C}$. It is hypothesised that MP isomerisation reactions may be moderated by the sulfide minerals.

\section{Acknowledgements}

This study was conducted as part of the CSIRO Flagship Collaboration Fund Cluster for Organic Geochemistry of Mineral Systems, led by Curtin University. A.H. thanks Curtin University for an Australia Postgraduate Award scholarship and CSIRO for a top-up scholarship. Geoff Chidlow and Lyndon Berwick provided technical support for MSSVpy and GC-MS analysis. Katy Evans is thanked for her insightful comments on the manuscript. Associate Editor Geoffrey Abbott, Andrew Gize and an anonymous reviewer are acknowledged for their helpful reviews and patience with our subsequent response.

\section{Associate Editor-Geoffrey Abbott}

\section{References}

Alexander, R., Bastow, T.P., Fisher, S.J., Kagi, R.I., 1995. Geosynthesis of organic compounds: II. Methylation of phenanthrene and alkylphenanthrenes. Geochimica et Cosmochimica Acta 59, 4259-4266.

Berwick, L.J., Greenwood, P.F., Smernik, R.J., 2010. The use of MSSV pyrolysis to assist the molecular characterisation of aquatic natural organic matter. Water Research 44, 3039-3054.

Blumer, M., 1975. Curtisite, idrialite and pendletonite, polycyclic aromatic hydrocarbon minerals: their composition and origin. Chemical Geology 16, $245-256$.

Boreham, C.J., Crick, I.H., Powell, T.G., 1988. Alternative calibration of the Methylphenanthrene Index against vitrinite reflectance: application to maturity measurements on oils and sediments. Organic Geochemistry 12, 289-294.
Brocks, J.J., Schaeffer, P., 2008. Okenane, a biomarker for purple sulfur bacteria (Chromatiaceae), and other new carotenoid derivatives from the $1640 \mathrm{Ma}$ Barney Creek Formation. Geochimica et Cosmochimica Acta 72, 1396-1414.

Brocks, J.J., Buick, R., Logan, G.A., Summons, R.E., 2003. Composition and syngeneity of molecular fossils from the 2.78 to 2.45 billion-year-old Mount Bruce Supergroup, Pilbara Craton, Western Australia. Geochimica et Cosmochimica Acta 67, 4289-4319.

Brocks, J.J., Love, G.D., Summons, R.E., Knoll, A.H., Logan, G.A., Bowden, S.A., 2005. Biomarker evidence for green and purple sulphur bacteria in a stratified Palaeoproterozoic sea. Nature 437, 866-870.

Brocks, J.J., Grosjean, E., Logan, G.A., 2008. Assessing biomarker syngeneity using branched alkanes with quaternary carbon (BAQCs) and other plastic contaminants. Geochimica et Cosmochimica Acta 72, 871-888.

Bull, S.W., 1998. Sedimentology of the Palaeoproterozoic Barney Creek formation in DDH BMR McArthur 2, southern McArthur basin, Northern Territory. Australian Journal of Earth Sciences 45, 21-31.

Chen, J., Walter, M.R., Logan, G.A., Hinman, M.C., Summons, R.E., 2003. The Paleoproterozoic McArthur River (HYC) Pb/Zn/Ag deposit of northern Australia: organic geochemistry and ore genesis. Earth and Planetary Science Letters 210, 467-479.

Cleaves, H.J., Michalkova Scott, A., Hill, F.C., Leszczynski, J., Sahai, N., Hazen, R., 2012 Mineral-organic interfacial processes: potential roles in the origins of life. Chemical Society Reviews 41, 5502-5525.

Cody, G.D., Boctor, N.Z., Brandes, J.A., Filley, T.R., Hazen, R.M., Yoder Jr., H.S., 2004 Assaying the catalytic potential of transition metal sulfides for abiotic carbon fixation. Geochimica et Cosmochimica Acta 68, 2185-2196.

Crick, I.H., 1992. Petrological and maturation characteristics of organic matter from the Middle Proterozoic McArthur Basin, Australia. Australian Journal of Earth Sciences 39, 501-519.

Davidson, G.J., Dashlooty, S.A., 1993. The Glyde Sub-basin: a volcaniclastic-bearing pull-apart basin coeval with the McArthur River base-metal deposit, Northern Territory. Australian Journal of Earth Sciences 40, 527-543.

Dick, J.M., Evans, K.A., Holman, A.I., Jaraula, C.M.B., Grice, K., 2013. Estimation and application of the thermodynamic properties of aqueous phenanthrene and isomers of methylphenanthrene at high temperature. Geochimica et Cosmochimica Acta 122, 247-266.

Donnelly, T.H., Jackson, M.J., 1988. Sedimentology and geochemistry of a midProterozoic lacustrine unit from northern Australia. Sedimentary Geology 58, $145-169$.

Eldridge, C.S., Williams, N., Walshe, J.L., 1993. Sulfur isotope variability in sedimenthosted massive sulfide deposits as determined using the ion microprobe SHRIMP: II. A study of the H.Y.C. deposit at McArthur River, Northern Territory, Australia. Economic Geology 88, 1-26.

Fetzer, J.C., Simoneit, B.R.T., Budzinski, H., Garrigues, P., 1996. Identification of large PAHs in bitumens from deep-sea hydrothermal vents. Polycyclic Aromatic Compounds 9, 109-120.

Garrigues, P., De Sury, R., Angelin, M.L., Bellocq, J., Oudin, J.L., Ewald, M., 1988. Relation of the methylated aromatic hydrocarbon distribution pattern to the maturity of organic matter in ancient sediments from the Mahakam delta. Geochimica et Cosmochimica Acta 52, 375-384.

Gizè, A.P., 1999. Organic alteration in hydrothermal sulfide ore deposits. Economic Geology 94, 967-979.

Greenwood, P.F., Leenheer, J.A., McIntyre, C., Berwick, L.J., Franzmann, P.D., 2006. Bacterial biomarkers thermally released from dissolved organic matter. Organic Geochemistry 37, 597-609.

Greenwood, P.F., Lengkeek, N.A., Piggott, M.J., Pierce, K., 2009. Structural identification and mass spectral interpretation of $\mathrm{C} 3 \mathrm{n}$ highly branched alkanes in sediment and aquatic extracts and evidence for their anthropogenic origin. Organic Geochemistry 40, 1055-1062.

Greenwood, P.F., Brocks, J.J., Grice, K., Schwark, L., Jaraula, C.M.B., Dick, J.M., Evans, K.A., 2013. Organic geochemistry and mineralogy. I. Characterisation of organic matter associated with metal deposits. Ore Geology Reviews 50, 1-27.

Grice, K., Schaeffer, P., Schwark, L., Maxwell, J.R., 1996. Molecular indicators of palaeoenvironmental conditions in an immature Permian shale (Kupferschiefer, Lower Rhine Basin, north-west Germany) from free and S-bound lipids. Organic Geochemistry 25, 131-147.

Grice, K., Schaeffer, P., Schwark, L., Maxwell, J.R., 1997. Changes in palaeoenvironmental conditions during deposition of the Permian Kupferschiefer (Lower Rhine Basin, northwest Germany) inferred from molecular and isotopic compositions of biomarker components. Organic Geochemistry 26, 677-690.

Grosjean, E., Logan, G.A., 2007. Incorporation of organic contaminants into geochemical samples and an assessment of potential sources: examples from Geoscience Australia marine survey S282. Organic Geochemistry 38, 853-869.

Hartgers, W.A., Sinninghe Damsté, J.S., Requejo, A.G., Allan, J., Hayes, J.M., Ling, Y. Xie, T.-M., Primack, J., de Leeuw, J.W., 1994. A molecular and carbon isotopic study towards the origin and diagenetic fate of diaromatic carotenoids. Organic Geochemistry 22, 703-725.

Holman, A.I., Grice, K., Jaraula, C.M.B., Schimmelmann, A., Brocks, J.J., 2012 Efficiency of extraction of polycyclic aromatic hydrocarbons from the Paleoproterozoic Here's Your Chance $\mathrm{Pb} / \mathrm{Zn} / \mathrm{Ag}$ ore deposit and implications for a study of Bitumen II. Organic Geochemistry 52, 81-87.

Holman, A.I., Grice, K., Jaraula, C.M.B., Schimmelmann, A., 2014. Bitumen II from the Paleoproterozoic Here's Your Chance $\mathrm{Pb} / \mathrm{Zn} / \mathrm{Ag}$ deposit: implications for the analysis of depositional environment and thermal maturity of hydrothermallyaltered sediments. Geochimica et Cosmochimica Acta 139, 98-109. 
Horsfield, B., Disko, U., Leistner, F., 1989. The micro-scale simulation of maturation: outline of a new technique and its potential applications. Geologische Rundschau 78, 361-373.

Horsfield, B., Leistner, F., Hall, K., 2015. Microscale sealed vessel pyrolysis. In: Grice, K. (Ed.), Principles and Practice of Analytical Techniques in Geosciences. Royal Society of Chemistry, Oxford, pp. 209-250.

Huston, D.L., Stevens, B., Southgate, P.N., Muhling, P., Wyborn, L., 2006. Australian $\mathrm{Zn}-\mathrm{Pb}-\mathrm{Ag}$ ore-forming systems: a review and analysis. Economic Geology 101, 1117-1157.

Ireland, T., Large, R.R., McGoldrick, P., Blake, M., 2004. Spatial distribution patterns of sulfur isotopes, nodular carbonate, and ore textures in the McArthur River (HYC) Zn-Pb-Ag deposit, Northern Territory, Australia. Economic Geology 99, 1687-1709.

Kawka, O.E., Simoneit, B.R.T., 1990. Polycyclic aromatic hydrocarbons in hydrothermal petroleums from the Guaymas Basin spreading center. Applied Geochemistry 5, 17-27.

Koopmans, M.P., Köster, J., van Kaam-Peters, H.M.E., Kenig, F., Schouten, S., Hartgers, W.A., de Leeuw, J.W., Sinninghe Damsté, J.S., 1996. Diagenetic and catagenetic products of isorenieratene: molecular indicators for photic zone anoxia. Geochimica et Cosmochimica Acta 60, 4467-4496.

Ladjavardi, M., Berwick, L.J., Grice, K., Boreham, C.J., Horsfield, B., 2013. Rapid offline isotopic characterisation of hydrocarbon gases generated by micro-scale sealed vessel pyrolysis. Organic Geochemistry 58, 121-124.

Lahav, N., Chang, S., 1976. The possible role of solid surface area in condensation reactions during chemical evolution: reevaluation. Journal of Molecular Evolution 8, 357-380.

Landais, P., Michels, R., Elie, M., 1994. Are time and temperature the only constraints to the simulation of organic matter maturation? Organic Geochemistry 22, 617-630.

Large, D.J., Gizè, A.P., 1996. Pristane/phytane ratios in the mineralized Kupferschiefer of the Fore-Sudetic Monocline, southwest Poland. Ore Geology Reviews 11, 89-103.

Large, R.R., Bull, S.W., Cooke, D.R., McGoldrick, P.J., 1998. A genetic model for the HYC deposit, Australia: based on regional sedimentology, geochemistry, and sulfide-sediment relationships. Economic Geology 93, 1345-1368.

Le Métayer, P., Grice, K., Chow, C.N., Caccetta, L., Maslen, E., Dawson, D., Fusetti, L. 2014. The effect of origin and genetic processes of low molecular weight aromatic hydrocarbons in petroleum on their stable carbon isotopic compositions. Organic Geochemistry 72, 23-33.

Lewan, M.D., 1997. Experiments on the role of water in petroleum formation. Geochimica et Cosmochimica Acta 61, 3691-3723.

Lewan, M.D., Winters, J.C., McDonald, J.H., 1979. Generation of oil-like pyrolyzates from organic-rich shales. Science 203, 897-899.

Lockhart, R.S., Berwick, L.J., Greenwood, P., Grice, K., Kraal, P., Bush, R., 2013. Analytical pyrolysis for determining the molecular composition of contemporary monosulfidic black ooze. Journal of Analytical and Applied Pyrolysis 104, 640-652.

Logan, G.A., Hinman, M.C., Walter, M.R., Summons, R.E., 2001. Biogeochemistry of the 1640 Ma McArthur River (HYC) lead-zinc ore and host sediments, Northern Territory, Australia. Geochimica et Cosmochimica Acta 65, 2317-2336.

Maslen, E., Grice, K., Gale, J.D., Hallmann, C., Horsfield, B., 2009. Crocetane: potential marker of photic zone euxinia in thermally mature sediments and crude oils of Devonian age. Organic Geochemistry 40, 1-11.

McCollom, T.M., Simoneit, B.R.T., Shock, E.L., 1999. Hydrous pyrolysis of polycyclic aromatic hydrocarbons and implications for the origin of PAH in hydrothermal petroleum. Energy \& Fuels 13, 401-410.

McGoldrick, P., Winefield, P., Bull, S., Selley, D., Scott, R., 2010. Sequences, synsedimentary structures, and sub-basins: the where and when of SEDEX zinc systems in the southern McArthur Basin, Australia. In: Goldfarb, R.J., Marsh, E.E., Monecke, T. (Eds.), The Challenge of Finding New Mineral Resources: Global Metallogeny, Innovative Exploration, and New Discoveries. Volume II: Zinc-Lead, Nickel-Copper-PGE, and Uranium. Society of Economic Geologists Special Publication Number 15, Littleton, Colorado, pp. 367-389.

Nabbefeld, B., Grice, K., Schimmelmann, A., Summons, R.E., Troitzsch, U., Twitchett, RJ. 2010. A comparison of thermal maturity parameters between freely extracted hydrocarbons (Bitumen I) and a second extract (Bitumen II) from within the kerogen matrix of Permian and Triassic sedimentary rocks. Organic Geochemistry 41, 78-87.

Page, R.W., Sweet, I.P., 1998. Geochronology of basin phases in the western Mt Isa Inlier, and correlation with the McArthur Basin. Australian Journal of Earth Sciences 45, 219-232.
Peters, K.E., Walters, C.C., Moldowan, J.M., 2005. The Biomarker Guide: Volume 2 Biomarkers and Isotopes in Petroleum Exploration and Earth History. Cambridge University Press, Cambridge.

Price, L.C., 1993. Thermal stability of hydrocarbons in nature: limits, evidence, characteristics, and possible controls. Geochimica et Cosmochimica Acta 57, 3261-3280.

Püttmann, W., Merz, C., Speczik, S., 1989. The secondary oxidation of organic material and its influence on Kupferschiefer mineralization of southwest Poland. Applied Geochemistry 4, 151-161.

Radke, M., Welte, D.H., Willsch, H., 1982a. Geochemical study on a well in the Western Canada Basin: relation of the aromatic distribution pattern to maturity of organic matter. Geochimica et Cosmochimica Acta 46, 1-10.

Radke, M., Willsch, H., Leythaeuser, D., Teichmüller, M., 1982b. Aromatic components of coal: relation of distribution pattern to rank. Geochimica et Cosmochimica Acta 46, 1831-1848.

Rieger, A., Schwark, L., Cisternas, M.-E., Miller, H., 2008. Genesis and evolution of bitumen in Lower Cretaceous lavas and implications for strata-bound copper deposits, North Chile. Economic Geology 103, 387-404.

Rospondek, M.J., Marynowski, L., Góra, M., 2007. Novel arylated polyaromatic thiophenes: phenylnaphtho[b]thiophenes and naphthylbenzo[b]thiophenes as markers of organic matter diagenesis buffered by oxidising solutions. Organic Geochemistry 38, 1729-1756.

Rospondek, M.J., Marynowski, L., Chachaj, A., Góra, M., 2009. Novel aryl polycyclic aromatic hydrocarbons: phenylphenanthrene and phenylanthracene identification, occurrence and distribution in sedimentary rocks. Organic Geochemistry 40, 986-1004.

Safarik, I., Strausz, O.P., 1997. The thermal decomposition of hydrocarbons. Part 2. Alkylaromatic hydrocarbons: alkylbenzenes. Research on Chemical Intermediates 23, 63-99.

Schenk, H.J., Horsfield, B., 1993. Kinetics of petroleum generation by programmedtemperature closed-versus open-system pyrolysis. Geochimica et Cosmochimica Acta 57, 623-630.

Seewald, J.S., 2001. Aqueous geochemistry of low molecular weight hydrocarbons at elevated temperatures and pressures: constraints from mineral buffered laboratory experiments. Geochimica et Cosmochimica Acta 65, 1641-1664.

Simoneit, B.R.T., 1994. Lipid/bitumen maturation by hydrothermal activity in sediments of Middle Valley, Leg 139. In: Mottl, M.J., Davis, E.E., Fisher, A.T., Slack, J.F. (Eds.), Proceedings of the Ocean Drilling Program, Scientific Results, vol. 139. Ocean Drilling Program, College Station, Texas, pp. 447-465.

Simoneit, B.R.T., Lein, A.Y., Peresypkin, V.I., Osipov, G.A., 2004. Composition and origin of hydrothermal petroleum and associated lipids in the sulfide deposits of the Rainbow Field (Mid-Atlantic Ridge at $36^{\circ} \mathrm{N}$ ). Geochimica et Cosmochimica Acta 68, 2275-2294.

Sinninghe Damsté, J.S., Kohnen, M.E.L., Horsfield, B., 1998. Origin of low-molecularweight alkylthiophenes in pyrolysates of sulphur-rich kerogens as revealed by micro-scale sealed vessel pyrolysis. Organic Geochemistry 29, 1891-1903.

Stein, S.E., 1978. On the high temperature chemical equilibria of polycyclic aromatic hydrocarbons. The Journal of Physical Chemistry 82, 566-571.

Summons, R.E., Powell, T.G., 1987. Identification of aryl isoprenoids in source rocks and crude oils: biological markers for the green sulphur bacteria. Geochimica et Cosmochimica Acta 51, 557-566.

Sun, Y.-Z., 1998. Influences of secondary oxidation and sulfide formation on several maturity parameters in Kupferschiefer. Organic Geochemistry 29, 1419-1429.

Szczerba, M. Rospondek, M.J., 2010. Controls on distributions of methylphenanthrenes in sedimentary rock extracts: critical evaluation of existing geochemical data from molecular modelling. Organic Geochemistry $41,1297-1311$

van Aarssen, B.G.K., Bastow, T.P., Alexander, R., Kagi, R.I., 1999. Distributions of methylated naphthalenes in crude oils: indicators of maturity, biodegradation and mixing. Organic Geochemistry 30, 1213-1227.

Wächtershäuser, G., 1988. Before enzymes and templates: theory of surface metabolism. Microbiological Reviews 52, 452-484.

Williford, K.H., Grice, K., Logan, G.A., Chen, J., Huston, D., 2011. The molecular and isotopic effects of hydrothermal alteration of organic matter in the Paleoproterozoic McArthur River $\mathrm{Pb} / \mathrm{Zn} / \mathrm{Ag}$ ore deposit. Earth and Planetary Science Letters 301, 382-392.

Wise, S.A., Campbell, R.M., West, W.R., Lee, M.L., Bartle, K.D., 1986. Characterization of polycyclic aromatic hydrocarbon minerals curtisite, idrialite and pendletonite using high-performance liquid chromatography, gas chromatography, mass spectrometry and nuclear magnetic resonance spectroscopy. Chemical Geology 54, 339-357. 